\title{
Cerebral venous sinus thrombosis (CVST) associated with SARS-CoV-2 vaccines: clues for an immunopathogenesis common to CVST observed in COVID-19
}

\author{
Anna Teresa Mazzeo ${ }^{1 *}$ (D) Alberto Noto ${ }^{1}$, Alessio Asmundo², Francesca Granata ${ }^{3}$, Karol Galletta ${ }^{3}$, \\ Raffaella Mallamace ${ }^{1}$, Cesare De Gregorio ${ }^{4}$, Francesco Puliatti ${ }^{5}$, Maria Carolina Fazio ${ }^{6}$, Antonino Germano' ${ }^{7}$, \\ Caterina Musolino ${ }^{8}$ and Guido Ferlazzo ${ }^{9}$
}

\begin{abstract}
Severe acute respiratory syndrome coronavirus type 2 has been responsible for an unprecedented pandemic, and nowadays, several vaccines proved to be effective and safe, representing the only available strategy to stop the pandemic. While millions of people have safely received vaccine, rare and unusual thrombotic events have been reported and are undergoing investigations to elucidate their nature. Understanding initial trigger, underlying pathophysiology and the reasons for specific site localization of thrombotic events are a matter of debate. We here propose that rare cases of cerebral venous sinus thrombosis, a clinical event that may rapidly evolve to brain death, reported after COVID-19 vaccine, might be consequent to an immune response resulting in inflamed/ damaged endothelium, an event similar to that described for cases of cerebral venous sinus thrombosis reported during COVID-19 and not necessarily related to anti-Platelets Factor 4 antibodies, as recently described. Remarkably, in the two patients presenting at our hospital with cerebral venous sinus thrombosis and evolved to brain death, proper tissue perfusion and function maintenance allowed organ donation despite extensive thrombosis in the organ donors, with favorable outcome at 6 months.

Increased vigilance, close multidisciplinary collaboration, and further prospective research will help to better elucidate a very rare and still not fully understood pathophysiological event associated with vaccines for severe acute respiratory syndrome coronavirus 2.
\end{abstract}

Keywords: Cerebral venous sinus thrombosis, COVID-19, SARS-CoV2, Thrombosis, Thrombocytopenia, Vaccine, VITT, Brain death, Organ donation

Severe acute respiratory syndrome coronavirus type 2 (SARS-CoV-2) has been responsible for an unprecedented pandemic since its first description, late 2019. Less than 1 year since the first appearance of the virus on the scene, several vaccines proved to be effective and safe and received approval for emergency use. Vaccines

\footnotetext{
* Correspondence: annateresamazzeo@unime.it

'Division of Anesthesia and Critical Care. Department of Human Pathology G. Barresi, University of Messina, Messina, Italy

Full list of author information is available at the end of the article
}

are essential to mitigate the effects of the SARS-CoV2 virus on public health, and their importance is universally recognized as the only available strategy to stop the pandemic.

While millions of people have safely received vaccine, rare and unusual thrombotic events, termed vaccine-induced immune thrombotic thrombocytopenia (VITT), have been reported [1-11], with a mortality of $39-41 \%$, mainly for hemorrhagic or ischemic brain injury [6, 12]. Thrombotic events have been mainly associated with

(c) The Author(s). 2021 Open Access This article is licensed under a Creative Commons Attribution 4.0 International License, which permits use, sharing, adaptation, distribution and reproduction in any medium or format, as long as you give

appropriate credit to the original author(s) and the source, provide a link to the Creative Commons licence, and indicate if changes were made. The images or other third party material in this article are included in the article's Creative Commons licence, unless indicated otherwise in a credit line to the material. If material is not included in the article's Creative Commons licence and your intended use is not permitted by statutory regulation or exceeds the permitted use, you will need to obtain permission directly from the copyright holder. To view a copy of this licence, visit http://creativecommons.org/licenses/by/4.0/ 
adenoviral vector-based vaccines, but more rarely described also in association with mRNA vaccines [13-15].

Although VITT is an extremely rare complication, it might be fatal, especially when presenting as cerebral venous sinus thrombosis (CVST), and this has created diffuse concerns and stimulated research to elucidate underlying pathomechanisms.

In this article, we propose our viewpoint on the mechanisms underlying CVST associated with COVID-19 vaccines, a partially unknown clinical event that may rapidly evolve to brain death, and we briefly report two fatal cases of ChAdOx1 nCov-19 (Astrazeneca) vaccineassociated CVST and thrombocytopenia occurred at our institution.

VITT has been recently reported to occur 5 to 48 days, median 14, after anti-COVID-19 vaccination, with cerebral veins being the most common thrombotic site at presentation, followed by the deep veins of the legs, pulmonary arteries, and splanchnic-vein thrombosis [16]. The baseline platelet count and the presence of intracranial hemorrhage are independent predictors of death, with an observed mortality of $73 \%$ among patients with platelet counts below 30,000 per cubic millimeter and intracranial hemorrhage [16].

However, CVST has also been reported as a rare neurologic complication of COVID-19 [17-25]. Very importantly, CVST is rare in the general population as well as after adenovirus-based SARS-CoV-2 vaccination, but appears to be several-fold more common in hospitalized patients with COVID-19, with a reported weighted average of 2.4, 3.6 and 207.1 per million, respectively [23]. Similarly, in a large population of 537,913 COVID-19 patients, the absolute incidence of CVT was 42.8 per million patients and was significantly greater than in a matched control cohort [24]. In a retrospective multicenter study of 13,500 consecutive patients with COVID-19 hospitalized in the USA, CVST was reported with an incidence of 8.8 per 10,000 during a 3-month study, extremely higher than the expected incidence in the general population of 5 per million annually [25].

CVST associated with COVID-19 should represent the result of a prothrombotic inflammatory state caused by anti-SARS-CoV2 immune response targeting vessel endothelium, which express ACE2, i.e., one of the main cellular receptors for SARS-CoV2. Indeed, endothelial injury and microvascular inflammation are recognized as a feature of COVID-19 and a major contributor to hypercoagulability observed along the disease.

Because all vaccines currently approved in our country act via the production of virus-associated proteins able to target angiotensin-converting enzyme 2 (ACE2), also the immune response occurring after vaccine could putatively generate inflammatory events targeting vascular beds, similarly to COVID-19.
Nevertheless, clinical presentation of the recently published cases of VITT has been proposed to resemble heparin-induced thrombocytopenia (HIT), a lifethreatening complication of heparin treatment. HIT is caused by the production of platelet-activating IgG antibodies that recognize multimolecular complexes of (cationic) platelet factor 4 (PF4) bound to (polyanionic) heparin [26].

Clinical symptoms and laboratory features of this prothrombotic state have been described also in a subset of patients not having received heparin, referred as autoimmune HIT (aHIT) [26]. Indeed, besides heparin, other polyanions, such as DNA and RNA, polyphosphates and bacterial wall can induce the conformational changes in PF4 required to expose neo-antigens [26].

While most of the published reports hypothesized pathologic antibodies to PF4 as the keystone of VITT, similar to autoimmune HIT, we hypothesize that rare cases of CVST reported after vaccine might be also contributed by a prothrombotic event secondary to inflamed/damaged endothelium, similarly to what described for cases of CVST reported during COVID-19 and, thus, not necessarily related to anti-PF4 antibodies. The presence of anti-PF4 antibodies, which is detectable in $90 \%$ of vaccine-induced CVST patients [16], might be a concomitant phenomenon secondary to immunemediated cell damage leading to circulating DNA, another negatively charged compound that forms an immunogenic complex with the positively charged PF4. As mentioned above, nucleic acids are able to bind PF4 and change its conformation, eventually resulting in exposure of new epitopes responsible of auto-antibodies production [27]. Interestingly, an 11-month follow-up study demonstrated that anti-PF4 antibodies are transient in most patients with VITT and become negative in $66 \%$ of the patients [28]. Furthermore, the kinetics of anti-PF4 antibodies in VITT compared to HIT is currently unknown and requires further studies [29]. Molecular mimicry between spike protein and PF4 epitopes has also been proposed [30]. More importantly, following immunization with COVID-19 vaccine, CVST can occur in the absence of anti-PF4 antibodies [31].

Considering the timing of CVST occurrence upon vaccine administration, a role for vaccine-induced, antispike immune response appears likely. We envisage, as a hypothesis for VITT pathogenesis, that the vaccine could lead to an adaptive immune response able to eventually target and damage cells that express the receptors for the spike-associated proteins induced by the vaccine, including endothelial cells. In this instance, a main pathogenic role would be played by the presence of not yet identified individual predisposing factors, which call for further research to better elucidate the mechanism and guide future directions. 
The reasons why this immunogenic thrombosis preferentially occurs in cerebral venous vessels are still unclear, but a different density or polymorphism of specific immunoglobulin receptors (CD32) in endothelial cells might play a role [32]. Others suggest a strong expression of Coxsackie-adenovirus-receptors and adhesion molecules on central nervous system [33].

The endothelium contributes to the local balance between pro- and anti-inflammatory mediators as well as procoagulant and anticoagulant activities. Furthermore, in different vascular beds, endothelial cells exhibit properties that are specific of the local environment. This could further explain the different susceptibility of CVST as preferential site of VITT phenomena. Immunohistochemical findings of post-mortem examinations suggest endothelial activation sustaining procoagulant conditions and thrombus formation [34].

Given the physiological circulatory route of cerebrospinal fluid, thrombosis might occur due to the spread of vaccine-associated inflammatory mediators or effector cells to the vascular endothelium of the sinus venous or to direct extension into the sinus venous of the immunocomplexes present into the cerebrospinal fluid. Interestingly, SARS-CoV2 infection preceded the symptoms of CVST by up to two weeks, as reported in recent cases of VITT, which, again, represent the interval of time necessary for obtaining an effective adaptive immune response.

In Table 1 and Fig. 1, we present two fatal cases of ChAdOx1 nCov-19 (Astrazeneca) vaccine-associated CVST and thrombocytopenia, both complicated by cerebral hemorrhage rapidly evolving to brain death, that were admitted to our university hospital in March 2021. Worthwhile to signal, and in agreement with an immune-based pathogenesis associated with an endothelial injury, a high $\mathrm{ScvO} 2$ value occurred in case 2, which might therefore suggest an inability of the cells to extract oxygen or a micro-circulatory shunting due to endothelium damage.

Antibodies to platelet factor 4 (PF4) were positive in both patients, as previously described in some other reported cases of VITT [35]. Consistent with an assumed

Table 1 Characteristics and clinical course of two cases of cerebral venous sinus thrombosis post vaccination with ChAdOx1 nCoV19 presenting at our University hospital and evolving to brain death

\begin{tabular}{|c|c|c|}
\hline & Patient 1 & Patient 2 \\
\hline Age and sex & 55-years-old woman & 45-year-old man \\
\hline $\begin{array}{l}\text { Preexisting conditions and } \\
\text { screening for thrombophilia }\end{array}$ & $\begin{array}{l}\text { No preexisting conditions. } \\
\text { MTHFR A1298C homozygous mutation }\end{array}$ & $\begin{array}{l}\text { Body mass index of } 30 \\
\text { Screening negative }\end{array}$ \\
\hline $\begin{array}{l}\text { Symptoms and timing since } \\
\text { vaccine administration }\end{array}$ & $\begin{array}{l}\text { Low-grade fever and headache developed one week } \\
\text { after vaccination }\end{array}$ & History of headaches 23 days after vaccination \\
\hline $\begin{array}{l}\text { Admission clinical picture, } \\
\text { platelet count, and D-dimer (ref- } \\
\text { erence value } 0-0.5 \mathrm{ug} / \mathrm{ml} \text { ) }\end{array}$ & $\begin{array}{l}\text { Alert and cooperative, headache } \\
\text { Platelet count: } 31,000 \text { per cubic millimeter } \\
\text { D-dimer }>4 \mathrm{ug} / \mathrm{ml}\end{array}$ & $\begin{array}{l}\text { Acute focal neurologic motor deficit and altered level of } \\
\text { consciousness } \\
\text { Platelet count: } 125,000 \text { per cubic millimeter } \\
\text { D-dimer }>4 \mathrm{ug} / \mathrm{ml}\end{array}$ \\
\hline $\begin{array}{l}\text { Sites of thrombosis during } \\
\text { clinical course }\end{array}$ & $\begin{array}{l}\text { Pulmonary subsegmental arteries thrombosis } \\
\text { Thrombosis of the right internal jugular vein, absent } \\
\text { signal void at straight sinus and at right transverse sinus } \\
\text { (Fig. 1A-D) } \\
\text { Portal vein branch thrombosis and partial thrombosis of } \\
\text { inferior cava vein. Extension of thrombosis at mesenteric } \\
\text { superior vein, main branches of portal vein, and } \\
\text { sovraepatic branches }\end{array}$ & $\begin{array}{l}\text { Massive thrombosis of the right transverse-sigmoid and } \\
\text { of superior sagittal sinuses associated with a right intra- } \\
\text { cerebral hemorrhagic infarction and midline shift (Fig. } \\
1 \mathrm{E}-\mathrm{H} \text { ) } \\
\text { No signs of thrombosis were found in any other distric. }\end{array}$ \\
\hline Therapy and interventions & $\begin{array}{l}\text { Methylprednisolone, fondaparinux, intravenous } \\
\text { immunoglobulins }\end{array}$ & $\begin{array}{l}\text { Dexamethasone, fondaparinux, intravenous } \\
\text { immunoglobulins }\end{array}$ \\
\hline $\begin{array}{l}\text { Antibodies to platelet factor } 4 \text {, } \\
\text { reference value }<0.400 \text { OD }\end{array}$ & $1.126 \mathrm{OD}$ & $2.37 \mathrm{OD}$ \\
\hline Evolution & $\begin{array}{l}\text { Neurological deteriorations on day 2, pupils became } \\
\text { anisocoric, Glasgow Coma Scale was } 3 \\
\text { Cerebellar hemorrhage and diffuse cerebral edema with } \\
\text { transtentorial herniation } \\
\text { Emergency posterior decompressive craniectomy, } \\
\text { intracranial pressure monitoring, external ventricular } \\
\text { drainage. Refractory intracranial hypertension } \\
\text { Death by neurologic criteria was declared on day } 8\end{array}$ & $\begin{array}{l}\text { Pupils were dilated and fixed and Glasgow Coma Scale } \\
\text { was } 3 \text {. Neurosurgical consult excluded further } \\
\text { intervention for futility due to poor grade prognosis } \\
\text { Central venous oxygen saturation was } 92 \% \text {, without } \\
\text { clinical signs of sepsis } \\
\text { Death by neurologic criteria was declared on day } 3\end{array}$ \\
\hline $\begin{array}{l}\text { Organ donation and } \\
\text { transplanted organs }\end{array}$ & $\begin{array}{l}\text { Organ donation per previously expressed wish to donate } \\
\text { Kidneys and corneas transplanted }\end{array}$ & $\begin{array}{l}\text { Organ donation per previously expressed wish to } \\
\text { donate } \\
\text { Lungs, liver, kidneys. and corneas transplanted }\end{array}$ \\
\hline Outcome in organ recipients & Good at 6 months & Good at 6 months \\
\hline
\end{tabular}




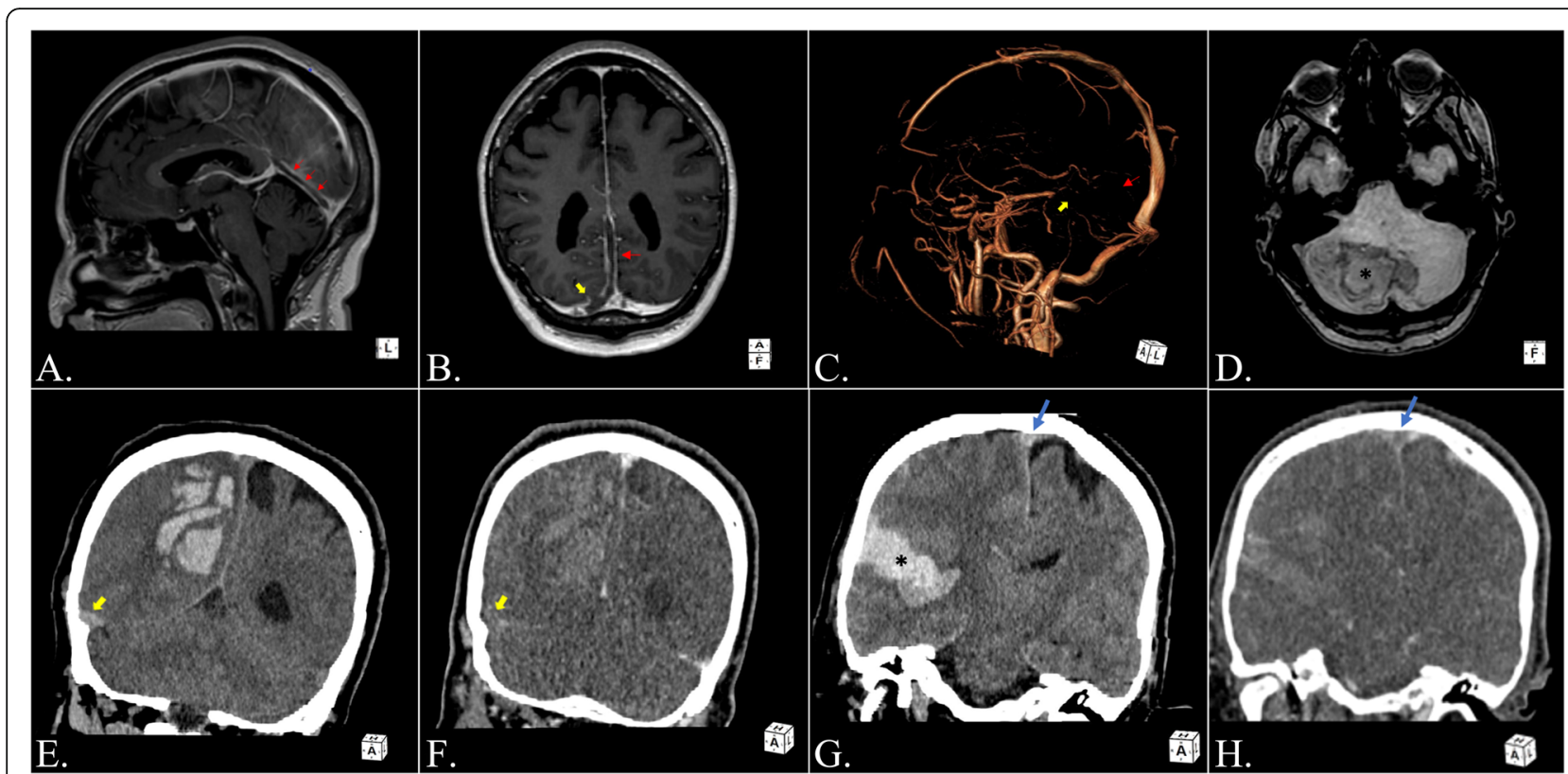

Fig. 1 Neuroradiological findings. Patient 1: A, D magnetic resonance imaging (MRI) examination. A, B Sagittal and coronal contrast-enhanced T1-weigthed images depict SS (red arrows) and right TS (yellow arrows) extensive thrombosis with filling defect inside the vessels. C Phasecontrast MRI angiography (PCA) with volume rendering technique shows lack of venous flow in SS (red arrow) and right TS (yellow arrow). D Susceptibility-weighted (SWI) follow-up MRI examination shows acute bilateral cerebellar hemisphere hematoma, prevalent on the right side (asterisk). Patient 2: E, $\mathbf{H}$ brain computed tomography (CT scan examination) at clinical onset. E Coronal unenhanced CT scan depicts large right parietal hematoma and ipsilateral TS hyperdensity ("Dense clot Sign"), indicated by yellow arrow. F Coronal enhanced CT scan shows lack of opacization of thrombosed right TS (yellow arrow). G Coronal unenhanced CT scan depicts right temporal hematoma (asterisk) and "Dense clot Sign" at SSS (blue arrow). H Coronal enhanced CT scan shows triangular area of enhancement with a relatively low-attenuating center ("Empty delta Sign") at thrombosed SSS (blue arrow). Straight sinus (SS), superior sagittal sinus (SSS), transverse sinus (TS)

autoimmune mechanism, treatments for these VITT were anticoagulants different from heparin (fondaparinux), high dose intravenous immunoglobulins and steroids [36, 37]. Despite treatment, deterioration of neurological picture occurred, with refractory intracranial hypertension leading to brain death. Following patient will and thanks to organ perfusion/function maintenance, despite severe acute thrombotic events, successful organ donation was possible in both cases, with 6 months good outcomes in recipients.

As VITT is a potentially fatal event associated with vaccine against a much more devastating pandemic, it is imperative that science move forward illuminated by wisdom and prudence. High index of suspicion and prompt diagnosis are extremely important to ensure immediate hospitalization and therapy [36, 37], since CVST associated with either vaccines or COVID-19 seems to evolve much more rapidly and with a higher level of fatalities than CVST with different etiology [38].

Finally, if brain death occurs, careful organ donor management, including mitigating inflammatory response, can allow functional organs to be successfully transplanted to save other lives.

\section{Abbreviations}

VITT: Vaccine-induced immune thrombotic thrombocytopenia; SARS-CoV2: Severe acute respiratory syndrome coronavirus 2; CVST: Cerebral venous sinus thrombosis; COVID-19: Coronavirus disease 2019; PF4: Platelet factor 4; HIT: Heparin-induced thrombocytopenia; aHIT: Autoimmune HIT; SS: Straight sinus; SSS: Superior sagittal sinus; TS: Transverse sinus; PCA: Phase-contrast angiography; SWI: Susceptibility-weighted; CT: Computed tomography; IVIG: Intravenous immunoglobulins; ACE2: Angiotensin-converting enzyme 2

\section{Acknowledgements}

None

\section{Authors' contributions}

ATM, AN, AA, and GF made substantial contribution to the initial conception of the work. ATM wrote the manuscript and completed the literature search. GF, AA, and AN critically revised the manuscript. FG and KG created the figure and were involved in drafting the case reports. AN, RM, and ATM drafted the case reports. CDG, FP, MCF, AG, and CM critically revised the manuscript. All listed authors approved the final version to be published.

\section{Funding}

No funding was received for the preparation of this article.

Availability of data and materials

Data sharing is not applicable to this article as no datasets were generated or analyzed during the current study. 


\section{Declarations}

\section{Ethics approval and consent to participate}

The Ethic Committee of the Hospital has been notified, as per local protocol, of the submission of the cases inside the manuscript for publication.

\section{Consent for publication}

Consent to Disclose for Publication of the two cases in Table 1 and Fig. 1 have been obtained from the family of each patient.

\section{Competing interests}

GF has received fees as a lecturer and consultant, as well as research grants from the following organizations: Lallemand Pharma, BG-Clinicals, Biogen, Beckman Coulter, Becton-Dickinson, PharmNDev. AA was appointed as technical consultant for the CEO for Italy of the AZD1222 vaccine manufacturer (Astra Zeneca) in a legal proceeding initiated by the Public Prosecutor's Office at the Court of Syracuse. AN has received fees for educational events on hemodynamic monitoring form Edwards Lifescience. ATM, FG, KG, RM, CDG, $F P, M C F, A G$, and $C M$ have no disclosures.

\section{Author details}

'Division of Anesthesia and Critical Care. Department of Human Pathology G. Barresi, University of Messina, Messina, Italy. ${ }^{2}$ Section of Legal Medicine, Department of Biomedical and Dental Sciences and Morphofunctional Imaging, University of Messina, Messina, Italy. ${ }^{3}$ Neuroradiology Unit, Department of Biomedical, Dental Science and Morphological and Functional Images, University of Messina, Messina, Italy. ${ }^{4}$ Cardiology Unit, Department of Clinical and Experimental Medicine, University of Messina, Messina, Italy. ${ }^{5}$ Transplant Coordination, A.O.U. Policlinico "G. Martino", Messina, Italy. ${ }^{6}$ U.O.S.D Stroke Unit. D.A.I. Emergenze Tempo Dipendenti. A.O.U. Policlinico "G. Martino", Messina, Italy. ${ }^{7}$ Division of Neurosurgery, BIOMORF Department, University of Messina, Messina, Italy. ${ }^{8}$ Division of Haematology, Department of Human Pathology G.Barresi, University of Messina, Messina, Italy. ' Laboratory of Immunology and Biotherapy, Department of Human Pathology G.Barresi and Cell Factory UniMe Research Center, Division of Clinical Pathology, A.O.U. Policlinico "G. Martino", University of Messina, Messina, Italy.

Received: 10 October 2021 Accepted: 2 November 2021

Published online: 18 November 2021

\section{References}

1. Schultz NH, Sørvoll $H_{H}$, Michelsen AE, Munthe LA, Lund-Johansen F, Ahlen MT, Wiedmann M, Aamodt A-H, Skattør TH, Tjønnfjord GE, Holme PA (2021) Thrombosis and thrombocytopenia after ChAdOx1 nCoV-19 vaccination. N Engl J Med 384(22):2124-2130. https://doi.org/10.1056/NEJMoa2104882

2. von Hundelshausen P, Lorenz R, Siess W, Weber C (2021) Vaccine-induced immune thrombotic thrombocytopenia (VITT): targeting pathomechanisms with bruton tyrosine kinase inhibitors. Thromb Haemost. 121(11):1395-1399. https://doi.org/10.1055/a-1481-3039

3. Oldenburg J, Klamroth R, Langer F, Albisetti M, von Auer C, Ay C, Korte W, Scharf RE, Pötzsch B, Greinacher A (2021) Erratum: Diagnosis and management of vaccine-related thrombosis following AstraZeneca COVID19 vaccination: guidance statement from the GTH. Hamostaseologie. 41(3): e1. https://doi.org/10.1055/s-0041-1729135

4. Cines DB, Bussel JB (2021) SARS-CoV-2 vaccine-induced immune thrombotic thrombocytopenia. N Engl J Med N Engl J Med. 384(23):2254-2256. https:// doi.org/10.1056/NEJMe2106315

5. Greinacher A, Thiele T, Warkentin TE, Weisser K, Kyrle PA, Eichinger S (2021) Thrombotic thrombocytopenia after ChAdOx1 nCov-19 vaccination. N Engl J Med N Engl J Med. 384(22):2092-2101. https://doi.org/10.1056/NEJMoa21 04840

6. Dotan A, Shoenfeld $Y$ (2021) Perspectives on vaccine induced thrombotic thrombocytopenia. J Autoimmun. 121:102663. https://doi.org/10.1016/j.ja ut.2021.102663

7. See I, Su JR, Lale A, Woo EJ, Guh AY, Shimabukuro TT, Streiff MB, Rao AK, Wheeler AP, Beavers SF, Durbin AP, Edwards K, Miller E, Harrington TA, MbaJonas A, Nair N, Nguyen DT, Talaat KR, Urrutia VC, Walker SC, Creech CB, Clark TA, DeStefano F, Broder KR (2021) US case reports of cerebral venous sinus thrombosis with thrombocytopenia after Ad26.COV2.S vaccination,
March 2 to April 21, 2021. JAMA 325(24):2448-2456. https://doi.org/10.1001/ jama.2021.7517

8. Muir K-L, Kallam A, Koepsell SA, Gundabolu K (2021) Thrombotic thrombocytopenia after Ad26.COV2.S vaccination. N Engl J Med. 384(20): 1964-1965. https://doi.org/10.1056/NEJMc2105869

9. Scully $M$, Singh $D$, Lown $R$, Poles A, Solomon $T$, Levi $M$, Goldblatt $D$, Kotoucek P, Thomas W, Lester W (2021) Pathologic antibodies to platelet factor 4 after ChAdOx1 nCoV-19 vaccination. N Engl J Med 384(23):22022211. https://doi.org/10.1056/NEJMoa2105385

10. Perry RJ, Tamborska A, SinghB, Craven B, Marigold R, Arthur-Farraj P, Yeo JM, Zhang L, Hassan-Smith G, Jones M, Hutchcroft C, Hobson E, Warcel D, White D, Ferdinand P, Webb A, Solomon T, Scully M, Werring DJ, Roffe C, CVT after immunisation against COVID-19 (CAIAC) collaborators (2021) Cerebral venous thrombosis after vaccination against COVID-19 in the UK: a multicentre cohort study. Lancet S0140-6736(21)01608-01601. doi: https:// doi.org/10.1016/S0140-6736(21)01608-1

11. Thakur KT, Tamborska A, Wood GK, McNeill E, Roh D, Akpan IJ, Miller EC, Bautista A, Claassen J, Kim CY, Guekht A, Pardo CA, Williams O, García-Azorín D, Prasad K, Schmutzhard E, Michael BD, Chou SHY, Winkler AS, Solomon T, Elkind MS (2021) Clinical review of cerebral venous thrombosis in the context of COVID-19 vaccinations: evaluation, management, and scientific questions. J Neurol Sci 427:117532. https://doi.org/10.1016/j.jns.2021.117532

12. Sharifian-Dorche $M$, Bahmanyar M, Sharifian-Dorche A, Mohammadi $P$, Nomovi M, Mowla A (2021) Vaccine-induced immune thrombotic thrombocytopenia and cerebral venous sinus thrombosis post COVID-19 vaccination; a systematic review. Neurol Sci 428:117607. https://doi.org/10.1 016/j.jns.2021.117607

13. Carli G, Nichele I, Ruggeri M, Barra S, Tosetto A (2021) Deep vein thrombosis (DVT) occurring shortly after the second dose of mRNA SARS-CoV-2 vaccine. Intern Emerg Med. 16(3):803-804. https://doi.org/10.1007/s11739-021-026850

14. Dias L, Soares-Dos-Reis R, Meira J, Ferrão D, Soares PR, Pastor A, Gama G, Fonseca L, Fagundes V, Carvalho M (2021) Cerebral venous thrombosis after BNT162b2 mRNA SARS-CoV-2 vaccine. J Stroke Cerebrovasc Dis. 30(8): 105906. https://doi.org/10.1016/j.jstrokecerebrovasdis.2021.105906

15. Smadja DM, Yue QY, Chocron R, Sanchez O, Lillo-Le Louet A (2021) Vaccination against COVID-19: insight from arterial and venous thrombosis occurrence using data from VigiBase. Eur Respir J. 2100956(1). https://doi. org/10.1183/13993003.00956-2021

16. Pavord S, Scully M, Hunt BJ, Lester W, Bagot C, Craven B, Rampotas A, Ambler G, Makris M (2021) Clinical features of vaccine-induced immune thrombocytopenia and thrombosis. N Engl J Med doi 385(18):1680-1689. https://doi.org/10.1056/NEJMoa2109908

17. Nwajei F, Anand P, Abdalkader M, Arasa VCA, Aparicio HJ, Behbahani S, Curiale G, Daneshmand A, Dasenbrock H, Mayo T, Mian A, Nguyen T, Ong C, Romero JR, Sakai O, Takahashi C, Cervantes-Arslanian AM (2020) Cerebral venous sinus thromboses in patients with SARS-CoV-2 infection: three cases and a review of the literature. J Stroke Cerebrovasc Dis 29(12):105412. https://doi.org/10.1016/j.jstrokecerebrovasdis.2020.105412

18. Hughes C, Nichols T, Pike M, Subbe C, Elghenzai S (2020) Cerebral venous sinus thrombosis as a presentation of COVID-19. Eur J Case Rep Intern Med 7:001691

19. Hemasian H, Ansari B (2020) First case of COVID-19 presented with cerebral venous thrombosis: a rare and dreaded case. Rev. Neurol. (Paris) 176(6):521523. https://doi.org/10.1016/j.neurol.2020.04.013

20. Klein DE, Libman R, Kirsch C, Arora R (2020) Cerebral venous thrombosis: a typical presentation of COVID-19 in the young. J Stroke Cerebrovasc Dis 29(8):104989. https://doi.org/10.1016/j.jstrokecerebrovasdis.2020.104989

21. Dakay K, Cooper J, Bloomfield J, Overby P, Mayer SA, Nuoman R, Sahni R, Gulko E, Kaur G, Santarelli J, Gandhi CD, Al-Mufti F (2021) Cerebral venous sinus thrombosis in COVID-19 infection: a case series and review of the literature. J Stroke Cerebrovasc Dis 30(1):105434. https://doi.org/10.1016/j. jstrokecerebrovasdis.2020.105434

22. Cavalcanti DD, Raz E, Shapiro M, Dehkharghani S, Yaghi S, Lillemoe K, Nossek E, Torres J, Jain R, Riina HA, Radmanesh A, Nelson PK (2020) Cerebral venous thrombosis associated with COVID-19. AJNR Am J Neuroradiol 41(8): 1370-1376. https://doi.org/10.3174/ajnr.A6644

23. Bikdeli B, Chatterjee S, Arora S, Monreal M, Jimenez D, Krumholz HM, Goldhaber SZ, Elkind MSV, Piazza G (2021) Cerebral venous sinus thrombosis in the U.S. population, after adenovirus-based SARS-CoV-2 vaccination, and after COVID-19. J Am Coll Cardiol 78(4):408-411. https://doi.org/10.1016/j.ja cc.2021.06.001 
24. Taquet M, Husain M, Geddes JR, Luciano S, Harrison PJ (2021) Cerebral venous thrombosis and portal vein thrombosis: a retrospective cohort study of 537,913 COVID-19 cases. EClinicalMedicine 39:101061. https://doi.org/10.1 016/.eclinm.2021.101061

25. Al-Mufti F, Amuluru K, Sahni R, Bekelis K, Karimi R, Ogulnick J, Cooper J, Overby P, Nuoman R, Tiwari A, Berekashvili K, Dangayach N, Liang J, Gupta G, Khandelwal P, Dominguez JF, Sursal T, Kamal H, Dakay K, Taylor B, Gulko E, El-Ghanem M, Mayer SA, Gandhi C (2021) Cerebral venous thrombosis in COVID-19: a New York Metropolitan cohort study. Am J Neuroradiol 42(7): 1196-1200. https://doi.org/10.3174/ajnr.A7134

26. Greinacher A, Selleng K, Warkentin TE (2017) Autoimmune heparin-induced thrombocytopenia. J Thromb Haemost. 15(11):2099-2114. https://doi.org/1 $0.1111 /$ jth. 13813

27. Chong BH, Chong JJ-H (2013) HIT: nucleic acid masquerading as heparin. Blood 122(2):156-158. https://doi.org/10.1182/blood-2013-05-504126

28. Schönborn L, Thiele T, Kaderali L, Greinacher A (2021) Decline in pathogenic antibodies over time in VITT. N Engl J Med 2112760(19):1815-1816. https:// doi.org/10.1056/NEJMc2112760

29. Othman M, Baker AT, Gupalo E, Elsebaie A, Bliss CM, Rondina MT, Lillicrap D, Parker AL (2021) To clot or not to clot? Ad is the question-insights on mechanisms related to vaccine-induced thrombotic Thrombocytopenia. J Thromb Haemost.19:2845-2856.

30. McGonagle D, De Marco G, Bridgewood C (2021) Mechanisms of immunothrombosis in vaccine-induced thrombotic thrombocytopenia (VITT) compared to natural SARS-CoV-2 infection. Journal of Autoimmunity 121:102662. https://doi.org/10.1016/j.jaut.2021.102662

31. Dutta A, Ghosh R, Bhattacharya D, Bhat S, Ray A, Pandit A, Das S, Dubey S (2021) Anti-PF4 antibody negative cerebral venous sinus thrombosis without thrombocytopenia following immunization with COVID-19 vaccine in an elderly non-comorbid Indian male, managed with conventional heparin-warfarin based anticoagulation. Case Reports Diabetes Metab Syndr. 15(4):102184. https://doi.org/10.1016/j.dsx.2021.06.021

32. Amiral J, Vissac AM (2019) Update on mechanisms, pathogenicity, heterogeneity of presentation, and laboratory diagnosis of heparin-induced thrombocytopenia. DOI. https://doi.org/10.5772/intechopen.86475

33. De Cristofaro R, Sanguinetti M (2021) Vaccine-induced thrombotic thrombocytopenia, a rare but severe case of friendly fire in the battle against COVID-19 pandemic: what pathogenesis? Eur J Intern Med 91:88-89. https://doi.org/10.1016/.ejim.2021.06.020

34. Pomara C, Sessa F, Ciaccio M, Dieli F, Esposito M, Garozzo SF, Giarratano A, Prati D, Rappa F, Salerno M, Tripodo C, Zamboni P, Mannucci PM (2021) Post-mortem findings in vaccine-induced thrombotic thombocytopenia. Haematologica 106(8):2291-2293. https://doi.org/10.3324/haematol.2021.2 79075

35. Marchandot B, Carmona A, Trimaille A, Curtiaud A, Morel O (2021) Procoagulant microparticles: a possible link between vaccine-induced immune thrombocytopenia (VITT) and cerebral sinus venous thrombosis. Thromb Thrombolysis. 1-3. 52(3):689-691. https://doi.org/10.1007/s11239021-02505-4

36. Oldenburg J, Klamroth R, Langer F, Albisetti M, von Auer C, Ay C, Korte W, Scharf RE, Pötzsch B, Greinacher A (2021) Diagnosis and management of vaccine-related thrombosis following AstraZeneca COVID-19 vaccination: guidance statement from the GTH. Hamostaseologie 41(3):184-189. https:// doi.org/10.1055/a-1469-7481

37. Furie KL, Cushman M, MSV E, Lyden PD, Saposnik G, American Heart Association/American Stroke Association Stroke Council Leadership (2021) diagnosis and management of cerebral venous sinus thrombosis with vaccine-induced immune thrombotic thrombocytopenia. Stroke 52(7):24782482. https://doi.org/10.1161/STROKEAHA.121.035564

38. Ferro JM, Canhao P, Stam J, Bousser MG, Barinagarrementeria F, for the ISCV T Investigators (2004) Prognosis of cerebral vein and dural sinus thrombosis. Results of the International Study on Cerebral Vein and Dural Sinus Thrombosis (ISCVT). Stroke 35(3):664-670. https://doi.org/10.1161/01.STR. 0000117571.76197 .26

\section{Publisher's Note}

Springer Nature remains neutral with regard to jurisdictional claims in published maps and institutional affiliations.

\section{Ready to submit your research? Choose BMC and benefit from:}

- fast, convenient online submission

- thorough peer review by experienced researchers in your field

- rapid publication on acceptance

- support for research data, including large and complex data types

- gold Open Access which fosters wider collaboration and increased citations

- maximum visibility for your research: over $100 \mathrm{M}$ website views per year

At BMC, research is always in progress.

Learn more biomedcentral.com/submissions 